\title{
Comparative Analysis of Dominance and Resistance in the Rhetoric of Ahmadinejad and Hugo Chavez: A CDA Perspective
}

\author{
Syed Sajjad Ali \\ Lecturer in English NUML Peshawar campus \\ ssali@numl.edu.pk \\ Dr. Zahir Jang Khattak \\ Professor, Department of Language and Literature \\ Qurtuba University, Peshawar
}

\begin{abstract}
This article intends to compare the speeches of Mahmoud Ahmadinejad and Hugo Chavez with the help of Critical Discourse Analysis. This article has applied Van Dijk's theoretical framework to dig out the issues of domination, imperialism, violence, resistance and injustice not only in a social context but also in a political arena inculcated in speeches. The research has analyzed one speech of each president qualitatively to investigate the concepts of resistance against the hegemonic domination of the US. The study finds that both the leaders have utilized positive selfrepresentation and negative other representation with the help of discursive devices. The study has also found the brutality, domination and injustice of the US. There may be found ideological similarities between the two presidents' positions over the imperialist designs. They are agreed that certain global powers' incursions and hegemonies need to be resisted due to their designs of imperialism and hegemony in places like the Middle East and Venezuela. The Study recommends that resistance rhetoric in politics can be significantly helpful in terms of international political diplomacies and policies for the nations of the world.
\end{abstract}

Keywords: CDA, Resistance, domination, injustice, discursive devices, positive selfrepresentation, negative other representation

\section{Introduction}

The roots of CDA are classical rhetoric, text linguistics, socio-linguistics, applied linguistics and pragmatics and some of its ideas can already be found in Jürgen Habermas and the Frankfurt School's critical theory prior to the Second World War (van Dijk, 2015). Critical Linguistics, which originated mainly in the UK and Australia at the end of the 1970s, looked to be a Critical Linguistics-based CDA (Wodak, 2011). CDA explains how public debate and attitudes can be dominated by the symbolic elites of politics and mass media and can thus lead to the reproduction of racism and xenophobia in the nation (Rogers et al., 2005). In the same vein, the two renowned leaders of their times: Hugo Chavez, president of Venezuela from 1999 to 2013 and 
Mahmoud Ahmadinejad, Iranian president (2005-2013) resisted the US dominance and imperialism through their speeches.

Discourse Analysis of the Ahmadinejad and Hugo Chavez speeches, somewhat deploy the hegemony critically. As Ahmadinejad announced that currently, an anti-hegemonic and antiimperialist front is emerging, and all free nations and citizens seeking justice should join their hands together to build an extended front against the prevailing structure and thinking (Tayebipour, 2017). Within the broad field of discourse analysis, the word 'discourse' is used in many ways. It is structurally a fundamental unit of language and practically a fundamental focus on the use of language (Blommaert, \& Bulcaen, 2000; Fozi, 2016). Kress (1990) explains that Discourse Analysis pursuit is to reflect the internal structural relationships that bind the discourse units to each other: to define formal connection within it. This phase of reprocessing can involve different kinds of discourse power relations, including among others, direct or accessible support, enforcement, representation, legitimization, denial, alleviation or disguise of supremacy (Fairclough \& Wodak, 2008). Farrelly (2010) points out that CDA is not regarded as a holistic or shut-down paradigm with a certain set of principles, but as an approach or view that can change over time. Since the 1980s, his work on CDA focused particularly on the study of discursive racism by so-called 'symbolic elites,' theory and theories of meanings.

We should not ignore the importance of the environments, functions, effects and environments of the development and understanding of discourse in order to understand the various properties of 'internal' speech at semantic and strategic levels (Van Dijk, 1997)

The speeches of Hugo Chavez and Mahmoud Ahmadinejad reflect their resistance rhetoric against the US. Both have a long political career that the scholars have studied well. However, when in power, both Ahmadinejad and Chavez were often characterized as "populists" who were masters of predicting and profiting from the fears, concerns and hopes of the people. Populism frequently arises in terms of its economic background due to widespread poverty and high inequality in a country, although these circumstances are by no means sufficient because of successful populism in politics (Pereira, 2018). Hugo Chávez extensively used mediated discourse to interact and form the Bolivarian Revolution's intellectual foundations. Same for the 
Ahmadinejad, a president of Iran has also been observed using speeches in favour of his county and against the hegemony of US and Zionist. Furthermore, the linguistic element to carry out the critical evaluation of a political phenomenon is this body of text and speaking, is worthwhile in this research . This study would highlight the determination and courageous political attitudes of Hugo Chavez and Ahmadinejad's rhetoric and their aggressiveness against the hegemonic dominance of the US. The study will also compare their resistance rhetoric in order to find out similarities and differences in their speeches.

\section{Literature Review}

The discourse can be regarded as a system of thought or knowledge that exists independently. Accordingly, Foucault (1972), whose work focuses on the notion of 'discourse', says that speakers always use pre-existing speeches as means of communication in society. Those who want to exercise power must therefore inevitably draw on speeches to do this. In the speeches of Hugo Chavez and Ahmadinejad resistance against US hegemonic dominance can be observed. Nevertheless, speech often reinforces inequality in society when a multiplicity in society starts becoming "dominant" and is taken for granted and perceived as natural.

Discourse is ideological, because its purpose is to preserve the asymmetry of power relations on which societies are founded. Van Dijk (2015) says that discourse is a linguistic domain, structured by common assumptions as a unity.

Van Dijk (2015) states that for the discursive situations and components, CDA plays a vital role that is nothing, but, worthwhile for the presumption and promulgation of the linguistics linked to speeches or texts. This exercise provides the deliberation and execution of the hidden meanings of the text and speeches that have specific context and goals. Van Dijk also promotes the importance of the discursive analysis as it controls the mind with the help of planned actions.

Van Dijk (1995) shows that CDA is opposed to those groups and institutions which are in power and in solidarity with dominating groups. Its aim is to discover and then condemn the dominant discourses, and further cooperate in empowering the dominated groups. Van Dijk continued to say that CDA is a critical approach to the analysis of discourses; it is not a single method or theory. 
The political power of language has been established in modern times. Fairclough (1989) pointed out in his classical essay "Politics and English Language," that languages can be used mostly for conceptual use. To quote from his own words: "Defendable defense essentially covers political discourse and writing." (p. 23) Political debate covers a wide range of subjects.

Van Dijk (2015) argued, in a similar vein, that CDA was a field in which written and spoken texts were studied and analyzed to show discursive sources of power, dominance, inequality and inclination. Moreover, the analysts should not wait until they can invoke them on the basis of "power" or "misuse of power." Invoking them should be an informed and cautious effort to fill up the social and cultural forces that are first and foremost able to make the meeting possible and they must not be an imperialist move. This broader scope appears to be necessary to track the progress made by Chavez's political opponents and understand how his discourse revealed the enemies he opposes (Gualda, 2012). The two renowned leaders of their times: Hugo Chavez, president of Venezuela and Mahmoud Ahmadinejad Iranian president resisted the hegemonic dominance of the US. The political discourse related to Mahmood Ahmadinejad has been renowned through the approaches of his resistance speeches (Tayebipour , 2017). On the other hand, the Bolivarian Revolution saw its reflection in Aló Presidente, a phone-in show in which citizens could engage with President Chávez in a "battle of ideas" and potentially have a role in the conduct of politics and policies (Gualda, 2012).

President Chávez invested time and effort through discourse in anchoring the Bolivarian Revolution in Venezuelan history and culture (Wilpert, 2007). Therefore, the analysis of the discourse on the Aló Presidente stage debates that the Bolivarian Revolution constitutes a useful approach to understanding this political phenomenon (Abalo, 2015). This study conducted by Ablo (2015) examined the rhetorical frames used by President Chávez in Aló Presidente to characterize the Bolivarian Revolution, taking into account the relevance of the aforementioned theoretical framework to the study of the discourse and political movement of the Hugo Chavez. The study found that Chavez is well known for his vibrant rhetoric condemning capitalism, imperialism, and the United States as a masterful communication. 
Van Dijk (2005) believes that the discursive, contextual, and cognitive dimensions of the speeches and their participants should be scrutinized in order to study the political ideologies involved in both producing and understanding political discourse. A brief account of the context of the situation and cognitive dimensions of the discourse is therefore provided in what follows. Furthermore, President Ahmadinejad turns to the terrorist attack in Shiraz, alleged to have been planned and carried out by Israel, American officials and certain British elements. "The Zionist regime, American officials, and some British elements have declared that they want to kill senior Iranian officials in the sentence".(p. 32) Whether, international sanctions on Ahmadinejad were an attempt to make him under control, contrary to it, he did not care and spoke against USA furiously (Borszik, 2014).

The current study intends to compare the resistance speeches of the world renowned leaders Hugo Chavez and Ahmadinejad against US hegemony. Some of the events and lectures prolong the profound understanding of Hugo Chavez and Mahmoud Ahmadinejad. They both have a very long political career. A few months ago, Mahmoud Ahmadinejad declared during his funeral, "Chavez will certainly return with Jesus and the Perfect One to Earth". The two leaders, Chavez and Ahmadinejad, who shared a profound mutual love, are both out of politics, Chávez dead, and Ahmadinejad's out of politics. However, when Ahmadinejad and Chavez were in power, they were often characterized as 'populist' who predicted and took advantage of people's fears, worries and hopes. A study by Chaudhri and Fyke (2008) demonstrates that the visit by Iranian President Mahmoud Ahmadinejad to the United States in September 2007 is a result of the efforts that heads of state visits are making under the heading of public diplomacy. The study shows that Ahmadinejad has employed a variety of techniques (representation of responsibility, taxation of the blame, loan gain) and concomitant methods to justify himself, his actions and his policies, in order to broaden and extend his self-presentation system.

A comparative analysis of the speeches of Presidents Ahmadinejad and President Obama before the 65 th and sixty-seventh UNGA was carried out by SADEGHI and TABATABAI (2015), focusing on the use of 'justice' to expose their human rights ideas. Sadeghi \& Tabatabai (2015) have shown that in their speeches President Ahmadinejad used world 'justice' extensively as an 
active supporter of human rights and the stable world while in his three speeches, Obama avoided to employ the word 'justice'.

Safdari (2019) compared the nuclear policy by the two presidents; Ahmadinejad and Hassan Rouhani . Safdari found that when you look at Ahmadinejad's tract score, the score does not show 8 IAEA reported on 16 January 2016 (average mistrust of others). It shows the language of Ahmadinejad concerning battling bullies and opposition to those in the West simply suggests a mistrust and non-cooperation that is extremely critical of others. Ahmadinejad's stance is similar to the findings of Thaler, Nader, Chubin, Lynch, and Green (2010)) in which he finds that in catchphrases such as "resistance" and "stability," his strategy meant to resolve to fight against "bullies" and to safeguard Iran's rights (p. 96). Rouhani, on the other hand, similarly expressed mistrust and cynicism towards others' intentions with regard to his high mark on distrust towards others. However, Rouhani's insistence on "negotiations" and "commitment" to the western nations indicates the contrary. In addition, Rouhani and the UN negotiated various agreements. And Rouhani's IAEA suggests that he is prepared to compromise and rely on Western nations. Acts of Rouhani, not confrontation and alienation, are acts of collaboration. Rouhani's high mistrust scoring of others is therefore not expressed as has been seen in his words or acts so far.

According to Campbell (2020), Venezuela has the world's biggest proven petroleum reserves and is the third-largest U.S. petroleum source, but today it is a crisis country. In addition, under the Bush and Chávez administrations, relations between the US and Venezuela changed drastically. This conflict links with the emerging political, economic and humanitarian crises in Venezuela. The results were repressive law, hyperinflation, drought, death and mass emigration from the country. So his study, in this regard, compared the news between 2001 and 2008 that is national and Latin American news showing the relationship between the US-Venezuelan. The analysis of the content reveals that major U.S. and Latin American differences exist in the media coverage. As reporting on newspapers, in specific, shows that concentrated on Hugo Chavez Venezuela was more on US coverage while the attention of the Venezuelan's media was balanced on both Bush and Latin America. The U.S. coverage portrayed the stories on the domestic and foreign affairs situations of Venezuela even more negatively as compared to the coverage of Latin 
America. Moreover, the news coverage of the United States represented Bush and Hugo Chavez in and more neutral way, Chávez was more often characterized as an opponent of the United States.

The above discussion adds to the literature review and it reflects that the speeches of Hugo Chavez and Ahmadinejad have not been compared before. Thus the study intends to fill this gap left by other researchers.

In addition, both Chavez and Ahmadinejad have been observed well based on their speeches in relation to the USA and Western powers. All comparative factors of both the leaders have the essence of the Hegemony and freedom that favor the weak on powerful. In this sense of understanding, all of their speeches are the best sources to ponder over. Critically speaking, actor, authority, disclaimer, evidentially, polarization, hyperbole, irony etc. will be discussed thoroughly to dig out their resistance to US domination. After analyzing the speeches of both the leaders with the help of Van Dijk's theoretical underpinning, the researcher's main focus will be to compare the speeches of both of them and find out the reason for their resistance to US imperialism and hegemonic dominance.

\section{Research Methodology}

This research analyses qualitative speeches by leaders of the world, such as Hugo Chavez and Ahmadinejad. In global political debate, it is structured to examine power dynamics and hegemony. It is intended to compare and evaluate objectively the rhetoric of world leaders and investigate how power and hegemonic ties are built and maintained. The CDA model of van Dijk (2005) is used as the study's theoretical framework on the speeches of Hugo Chavez and Ahmadinejad.

\section{Critical Discourse Analysis}

While there are many ways to examine and criticize social inequality, the way we answer these questions and dimensions is to concentrate on the role of debates in the development and challenge of domination. Here dominance is defined by the exercise of social power, which leads to social inequality by elites, institutions or classes, including political, cultural, class, ethnic, racial and gender inequality. This phase of reprocessing can involve different kinds of discourse power relations, including, among others, direct or accessible support, enforcement, representation, legitimization, denial, alleviation or disguise of supremacy (Fairclough \& Wodak, 2008). In more 
depth, critical discourse analysts wish to know which text, vocabulary, or interaction mechanisms, strategies, or other characteristics play a part in these modes of reproduction. It is tempting to research more or less specifically the relationship between speech and power structures, on an empirical and sociopolitical level of discourse. This is effective and important often. Because of the difficulty and scope of its mission, the CDA is a trans-disciplinary approach (Van Dijk, 1997). A democratic criticism of those responsible for its perversion in the reproduction of domination and injustice is included in the discourse review here. In doing so, analysts of critical debate should be mindful of social and political problems. This means that CDA is ideological because 'every criticism by definition presupposes an applied ethics'.

\section{CDA and Van Dijk's Theoretical Framework}

Van Dijk is a researcher in the areas of semantic document, discourse analysis and analysis of critical discourse. Since the 1980s, his work at the CDA has focused particularly on the study of discursive racism by so-called 'symbolic elites,' theory and theories of meanings. The CDA model of Van Dijk (2005) as the study's theoretical structure has been defined well. He defines CDA as a form of analytical discourse study that focuses on the issues of violence, domination, and inequality of social power as introduced, replicated, and resisted in the social and political context through text and speaks (McGregor, 2003). Critical discourse analysts take an overt position as an unorthodox study; investigate and eventually resist social injustice (van Dijk, 2004). Social cognition and memory: components of the connective interface between discourse and context "The relation between the structure of the social structure and the structure of the discourse is not a direct but indirect one that passes through a kind of interface called social cognition" (Van Dijk, 2002a). Cognition, as Van Dijk says, enables semantic representations to be preserved that take on the most precious meaning.

Summing up the discussion, the briefly CDA promulgated by Van Dijk that CDA is a method of discourse analytical study that primarily studies the way in the social and political context of social power violence, domination, and injustice are introduced, replicated, and resisted by text and chat. The classification demonstrated by Rahimi and Riasati (2011) in one selected statements by Hugo Chavez and onespeech by Ahmadinejad reveals a shortened form of 
Van Dijk's theoretical underpinnings (micro and macro).Zeb (2015) further selected a few discursive devices from many of them. Then the researcher makes a small selection taking help from Zeb (2015), as mentioned below, from hundreds of such categories.

\section{Actor: Disclaimers: Euphemism: Generalization: Hyperbole: Irony: Polarization:} Vagueness: Victimization: Authority: Evidentiality Presupposition:

\section{Comparative Analysis}

The present article intends to compare the speeches of Hugo Chavez and Ahmadinejad addressed in UNGA. Thus, investigating the speeches delivered by Hugo Chavez and Ahmadinejad in UNGA. For this purpose, some COMPARATIVE excerpts of each president's UNGA talk on some of the same topics are presented here to reveal the ideological stances of the two presidents on the topics at the macro-level of analysis. Moreover, the researcher will also report the use of the discursive devices by the two presidents to identify where there were significant differences between the usages of the devices in the speeches of the presidents.

\section{Application of Van Dijk's CDA Model on Speeches of Hugo Chavez and Ahmadinejad}

Actor: The renowned leader Ahmadinejad promulgates a modern discursive technique that avoids American influence through negative portrayal of the US and a positive representation of Muslims. Then, in his speech, he addresses the positive characteristics of the US (Muslims) and THEM (USA). In the present, Ahmadinejad emphasizes on the positive qualities of the Islamic people and the negative features of the people of the West and the Council of the Union. In contrary, he presents the Western people in a very negative way. For instance, in the very beginning of this speech, he says, "I call upon all distinguished guests to forgive these ignorant people" (Ahmadinejad, 2009, p.4). On the other side, historical records indicate that Hugo Chávez' personalities have adopted different speech tactics against the resistance to Venezuela politics and certain Muslim nations, such as Afghanistan, Iraq, Lebanon, and others, to support them in their speeches. In his speech which he addressed in the sixty-first session of the UN General Assembly on 20th September 2006, he accused the US and Israel for the brutalities brought by them over the Muslim countries, including Iran, Iraq, Afghanistan, Lebanon and Palestine, etc.

\section{Positive Self-Representation}


The main aim of Chavez speeches is to highlight the negative face of the USA, and thus he concentrated more on the negative characteristics of the USA than on the positive characteristics of Venezuela and some Muslim nations. Just one example is specifically related to the positive representation of the oppressed peoples of the world, but not to the oppressors. As he resists the representation of the oppressed nations as extremists and claims quite confidently "no, it's not that we are extremists" (Chaves, 2006, p.5). On the other side, as also cited by Shakoury (2018) in his thesis, Ahmadinejad in is keen to see things in black and white and adopts strong political opinions (Alemi, Tajeddin \& Kondlaji, 2018; Sardabi, Biria, \& Azin, 2014; (Gowhary, Rahimi, Azizifar, \& Jamalinesari, 2015). He continued to put criticism of the Security Council's inequity, partiality, and unfairness that anticipates a time in the future to empower the world's suppressed Muslims. He believes that there will be a period in which the Muslims will be equal and the world's leaders would represent as the "ideal supreme society". In addition, Ahmadinejad focuses on the positive characteristics of Islam-associated people and the negative characteristics of the people of the Council of the USA. For instance, in the very beginning of this speech, he says, "I call upon all distinguished guests to forgive "these ignorant people" and Western countries as "coercive powers" (Ahmadinejad, 2009, p. 5).

\section{Negative Other-Representation}

Chávez speaks negatively against the Western nations. For instance, he calls the US an Empire and model of domination. The most crucial example to mention here is the description of the US president, George W. Bush, the 43rd US president. Chaves openly and very explicitly calls him The Devil. He says, "The Devil is in their home. The Devil, the Devil himself is in their home", "the Devil came here yesterday" (Chaves, 2006, p. 3). Further he mentions that "yesterday the Devil was here, in this very place. This table from where I speak still smells like sulfur" the President of the United States, who I call "The Devil," (Chaves, 2006). He terms Bush's speech as "The Devil's Recipe" and suggests that a psychiatrist is needed to analyze the Bush's speech. He goes on to call Bush the "tyrannical president" and opines that Bush's speech was "full of hypocrisy and full of cynicism”. On another occasion, he terms Bush as “Mr. Imperialist Dictator”. (Chaves, 2006, p. 6) 
Ahmadinejad, in the same vein, is quite negatively speaking against the West, who, at the beginning of his speech for example, said, 'I call upon all the common visitors, as the powers of coercion, to forgive these ignorant peoples' and to the western worlds. He opines that the people of US have the nuclear, chemical and biological weapons beyond limits and he describes those weapons as "the instruments of coercion and threat against other peoples and governments", (p.7) because they use these weapons as a threat to dominate the other countries of the world, particularly Iran, Palestine, Iraq, Lebanon, and many others.

To sum up, The application of positive self-representation and negative otherrepresentation (Van Dijk, 2005), Hugo Chavez and Ahmadinejad ideology was in line with the findings of most CDA studies, which demonstrate that politicians mostly portray in-group members positively to validate their actions and out-group members negatively to invalidate the actions of others.(e.g. Alemi, Tajeddin \& Kondlaji, 2018; Sardabi, Biria, \& Azin, 2014; Sabry, n. d.; Matić, 2012; Rashidi \& Souzandehfar, 2010; Darweesh \& Muzhir, 2016; Aladist \& Wahyudi, 2012). The same are also cited by Shakoury(2018) in his thesis.

Authority: In speeches, speakers quote different superiors or higher authorities in order to increase credibility and show their members of the group that they are correct and that the members of the Out-group are wrong. Hugo Chavez mentions in this speech various authorities in support of his members and the members of the Out-group (the US). A short analysis and discussion of Chavez's various authorities is as follows. Hugo Chávez mentions in this speech several authorities to prove the United States of America as an imperialist and oppressor and to reinforce his position on US imperialism. Chávez suggests that the members of the Assembly read Chomsky's book to understand the truth behind the present miserable situation of the world, particularly in the oppressed countries. In addition to Chomsky, Chávez also mentions Aristotle and the first Greeks as the bodies to make his resistance to U.S. imperialism more credible.

In his speech, Ahmadinejad cites some religious authorities, just like the two previous speeches. At the beginning of the speech, he mentions the authority of Almighty Allah. He firmly believes that the Almighty Allah is the supreme power and the world works according to His will, as a Muslim and representative of the Muslim world in the General Assembly. He mentions the 
authority of the Almighty Allah to give a message of peace to the world by saying that "He commands His creatures to support one another in virtue, good, and piety, and not in corruption and decadence." Then, to resist the power and oppression of one group (Westerns) over another (Muslims), he says: "The Almighty has not created human beings so that they could transgress against others and oppress the."(Ahmadinejad,2006, p.2). In this speech, Ahmadinejad mentioned several authorities in support of his members of the Group (Muslims) and against members of the Out-group (the US).

Evidentially: According to Hugo Chavez, Capitalism will destroy the world, whereas, Socialism will save it. The people of Venezuela and Bolivarian Alliance should stand up against capitalism and protect the mankind from its curse. In this speech, Chavez proves that the all the people of the US want peace but the government of US does not want peace, rather it wants to impose their domination, oppression and occupation on the less powerful nations of the world. To prove his stance, he provides various evidences against the domination and imperialism of the US. For instance, he refers to the wars brought upon Palestine and Lebanon by the US in which hundreds of thousands innocent people were brutally killed. Moreover, he mentions the hundred years of domination and oppression in Latin America and in the world and the bombs launched and exploded in Beirut by the US military forces (Chaves, 2006) which led to the death of thousands of innocent and helpless people.

Ahmadinejad gave various evidence to expose and resist the oppression of the US and Zionist in this speech, especially in the form of facts and figures. Some of his most valid evidence is discussed briefly. In this speech, Ahmadinejad provides various evidentialities to prove the Outgroup members as racists, cruel and to present them as a threat to humanity. He gives chronological evidences and talks about the middle ages where "thinkers and scientists were sentenced to death" in order to prevent the other races from coming into power. Then, he says, the age of slave trade and slavery started in which "innocent people in millions were separated from their families and loved ones to be captivated and taken to Europe and America under worse conditions" and finally the "dark period" which was also notorious for "lootings, and massacres of innocent people and occupations" (Ahmadinejad, 2009, p. 9) 
To conclude the above discussion, the researcher finds a similar ideological stance in their resistance speeches with the help of the rhetoric device 'Evidentiality'. They both have the same approach towards the injustice and dominance of the US and Zionists. Both of them provided evidence of US imperialism, occupation, and superiority.

Generalization: According to Van Dijk (2007), generalization is a rhetorical instrument in which producers of discourses take the example of a specific point or case and generalize themselves on one point. In this speech, the researcher could not find any instance of generalization used by Hugo Chavez. On the other hand, Ahmadinejad takes some concrete examples of misdeeds by the West, the United States of America, and makes generalizations based on these particular examples. As the examples show in this paragraph, he usually declared that the West murdered millions of innocent citizens, and those scientists and intellectuals were killed.

Euphemism: Instead of using blunt and casual terms euphemism is used which means voicing the concept in respectful words. The investigator was also unable to find any references for this predictor in the current expression. The researcher only found one instance of euphemism in this speech by Ahmadinejad. Ahmadinejad says the nations which rose up and began to fight for democracy and freedom have to pay a high price. Instead of the sentence being killed, Ahmadinejad likes to use the sentence lose life for members of the In-group to present it politely.

Disclaimer:In the present speech, Hugo Chavez uses very few instances of disclaimer. For instance, speaking about the domination of the US, he states that "we cannot allow this to occur, we cannot permit them to install a world dictatorship, to consolidate a world dictatorship" (Chaves, 2006, p. 3) and thus disowns the domination as well as the support of the domination of a country by the hands of others. On the other hand, there is no instance of disclaimer used by Ahmadinejad in his speech.

Hyperbole: The discursive device hyperbole refers to the exaggeration of the good deeds done by one's in-group and the bad deeds done by one's Out-group, primarily for the enhancement of meaning (Van Dijk, 2005, Rashidi \& Souzandehfar, 2010). President Hugo Chavez uses the discursive technique "hyperbole" in nearly every UNGA speech to warn the global community about the rise of terrorism, bloodshed, chaos, hypocrisy, domination, and their repercussions. As 
he exaggerates the negative aspect of the US President's speech and says that his speech was "full of cynicism, full of hypocrisy" and with this hypocrisy, the president "controls everything". Apart from this, while criticizing the US President's terming the bombing in Lebanon as crossfire in an exaggerated way, he says that it was an "Imperialist fire! Fascist fire! Murderous fire! Genocidal fire against the innocent people of Palestine and Lebanon by the Empire and Israel" (Chaves, 2006, p. 4).Similarly, speaking about the age of Slavery and Slave Trade, he exaggerated the sufferings of the slaves and opines that "innocent people in millions were captivated, kept in worse condition and separated from their families". In addition, he exaggerates the destructions caused by WWI and WWII by saying that "those horrific wars claimed about 100 million lives and left behind massive devastation (Ahmadinejad, 2009, p. 3). Vagueness: The analysis of data of discursive devices also reveals a significant variation in the use of the discursive device "vagueness" by the two leaders in their UNGA speeches. The term vagueness is applied by them for the purpose to resist the superpower of the world. Through this rhetorical device, they intended to mitigate the positive traits of the out-group members and resist their dominance and imperialism. According to the statistics presented, Ahmadinejad employed the device three times more than Hugo Chavez. The discursive device 'vagueness' is used by discourse producers for two different characteristics: lack of clarity in pointing to an object-keeping image, particularly when reducing the good characteristics of out-group members (Darweesh \& Muzhir, 2016); Rashidi \& Souzandehfar, 2010; Van Dijk, 2005). With President Ahmadinejad's unwillingness to name the countries and his readiness to reduce the good qualities of out-group members, the president's increased use of "vagueness" in his four UNGA speeches is not surprising. This finding is consistent with Alemi, Tajeddin, and Kondlaji (2018), who found that in his 2012 UNGA address, Ahmadinejad showed no propensity to link global problems such as widespread terrorism, violence, and so on to any specific nations or individuals in the globe. . In his speech, Ahmadinejad poses vague statement in his speech, "Over the last centuries, humanity has gone through tremendous suffering and pain" (Ahmadinejad, 2009, p.4)

These; Rashidi \& Souzandehfar, 2010; Van Dijk, 2005) also cited by Shakoury (2018). 
In his speech, Chavez has used vague statements.He refers to the meeting of the UNGA which had taken place in 2005, a year ago of the present speech, and says that "and we said something that today is completely confirmed" (Chaves, 2006, p.2). He does not clarify the word "something" and leaves the audience in a sort of confusion about what was discussed a year before the present speech.

Presupposition: The term Presupposition is an idea or proposition inserted in a discourse (oral or written) without any evidence of proof (Jones and Peccei, 2004, cited in Darweesh \& Muzhir, 2016, p. 43). President Ahmadinejad believes that "the opposition is afraid that clarity will destroy the raison d'être of this system", (p. 5)that the audience is aware of such occult facts which would ruin, if revealed, the cause of the opposition regime's life. In the speech, it was also claimed that a "analysis of the historically preceding realities" would remind us that violence and injustice have victimized justice, and so the notion that certain harsh realities exist throughout history, such as the brutality, oppression and oppression brought on the Muslim world by oppressors. Ahmadinejad uses the passive structures and says, "over the last centuries, humanity has gone through tremendous suffering and pain, scientist and thinkers were put to death and millions of people were captivated" (Ahmadinejad, 2009, p. 6).

In his address, Chávez put forward some suggestions for the re-foundation of the UN, as stated earlier, and the second of those suggestions are to take appropriate methods for tackling and settling global conflicts. In that sense, Chávez presupposes that how world conflicts are handled and resolved in the United States is not successful and that an effective method of tackling world conflicts is required of the forum. Furthermore, it presupposes that the methods of UN decisionmaking and discussion are not clear. In reality, he questions the impartiality and justice of the UN which presupposes the bias, injustice, and partiality of the UN in terms of taking decisions concerning the conflicts of the world. Chavez also highlights the negative side of the USA and the representatives of the $\mathrm{UN}$ in the fourth plan. He implies that "the position and powers of the Secretary-General of the United Nations must be strengthened." (Chaves, 2006, p.6) This presupposes the UN's abduction by some of the representatives of the US and Israel, and that the Secretary-General of the UN is unable to take any role in deciding on conflicts around the globe. 
He implies that the UN Secretary-General should be confident enough to decide by him or herself, without guidance from Western dominant imperialists.

All and all, in the above discussion, the researcher found that ideologically both the leaders have the same approach towards dominance, instability, chaos, imperialism, and hegemony. To compare the usages of the language, Hugo Chavez uses very harsh and direct language while Ahmadinejad is somehow soft in language usage against America, Zionist, and Western in some of his speeches. This agrees with earlier studies which show that presupposition is among the top discursive device to represent in-group members positively and out-group members negatively (Mazlum \& Afshin, 2016)

Irony: Irony is a rhetorical device and discursive strategy that differs entirely from the literal meaning of an expression. In speeches, irony is used to emphasize a point and to make a speech more arguing. It should be noted that ironies can be explicit or implicit, but have a significant effect on the significance and credibility of a discourse in both cases. Ahmadinejad uses several instances of irony in his current investigative speech to resist US imperialism. Some of these ironies were presented, discussed and discussed below. In this speech, Chavez criticizes US President G.W. Bush's definition of the word extremist. He ironically believes, "With his color, Bolivia's dignified President Evo Morales has nothing to do with the colour of the skin," but in Chavez the US president accuses people of being extremist in the colour of their skin. Everyone who is not American or does not come from Israel is an extremist, the President says. Besides this, Chávez criticizes the American President for calling the murders of Palestinians and Lebanon "cross-fire." He states that when asked about the innocent people killed in Palestine and Lebanon by the US president, the president replied that in the cross-fire he was murdered.

In the similar vein, this speech is full of the instances of ironies used by Ahmadinejad to present the United States in a negative way and to highlight their true (negative) picture to the world. In the beginning of his speech, he uses very ironical names for the United States, such as the 'victorious powers, the owner of wealth and power' and 'the conquerors of the world'. Similarly, he, very ironically states that the soul aim of the invasion of Afghanistan is to 'restore security, peace, and economic wellbeing of Afghanistan' 
Polarization: Polarization is a discourse approach that discourse producers use to divide In-group (US) participants (THEMs). The debate producers polarize persons into two binaries or concepts with this technique. Some binaries created by Chavez in this speech are as follows. The debate producers are polarizing people into two binaries or concepts through this technique. In the present voice, some binaries created by Chavez are the following. i. In this address, Chavez frequently refers to the USA and Israel as THEM and divides them from its country's citizens (Venezuela) as well as from the other undermined nations.

Following are some samples of the speech that illustrate the strong polarization of nations. "They want to make us believe that they have devised a political model, the fake elite democracy." "We are extremists; we demand full world liberty, equality between peoples and respect for domestic sovereignty". The U.S. democracy vs. the Aristotelian system of government: He claims that, while the so-called democratic system run by the US is biased, the democratic system that was proposed by Aristotle and other great Greek philosophers was genuinely democratic. It is important to research the true democratic system proposed by the Greek philosophers and Aristotle, in order to discover the essence and true face of the so-called democratic system of the United States, and to compare this present system with that of ancient times, which he thinks is very different from the democratic system of the United States. In comparison to the ancient Greeks' equal, unbiased and pure form of government, American democracy is biased, partial, and enforced by invasion, bombs, marines, and violence. According to Ahmadinejad, he polarizes it in the following way i. Oppression vs. Human Dignity According to Ahmadinejad, the oppression of certain nations by others' hands is totally contradictory to humanity's norms. He argues that "it is definitely not consistent with human dignity what afflicts humanity today" .To him, such as the poor and innocent people of Palestine, Lebanon and Iraq; wars carry hardship, misery and suffering. In the same speech, he argues on another occasion that "some attempt to control the world by relying on threats and weapons, while others live in danger and constant uncertainty.", and thus, A binary is created between the warmongers and the war victims. "Some invade the homeland of others, thousands of kilometres away from their borders, intervene in their affairs and control their oil and other resources and strategic routes, while others are bombed every day in 
their own homes;" he goes on to make this binary rather more clear" iii. IAEA and NPT's Rules; Ahmadinejad rejects and opposes the partial and biased rules and regulations of the ITEA and NPT.

To conclude, the current research compared the speeches of Ahmadinejad and Hugo Chavez in terms of the US's hegemony and domination, using Van Dijk's theoretical Framework. After comparison, the researcher found slight differences in their speeches as both these leaders used positive self-representation and negative other-representation's strategy to resist the US domination. Thus, for the variation in between the two presidents' speeches, the study explores that both used the discursive devices "implication," "presupposition," and "actor description" in their speeches. This is consistent with previous research, which found that polarization, presupposition, disclaimers, and implications are among the most effective discursive methods for favourably representing in-group members and portraying the out-group members negatively (Mazlum \& Afshin, 2016)

Moreover, exploring the subjects addressed in Hugo Chavez's and Ahmadinejad's UNGA speeches, as well as the ideological position taken in these talks, helped the researcher to clarify the differences and similarities between the two presidents' UNGA addresses at the macro-level of analysis. To critically analyze the speeches and compare, some extracts from each president's four UNGA speeches on some of the same subjects were provided for this purpose to show the two presidents' ideological positions on the topics at the macro-level of analysis.

\section{Summary of Findings}

The speeches of both Hugo and Ahmadinejad have been observed based on rhetoric, and prominently discourse of the powers. In this regard, all aspects of the speeches are highlighted in this study. The resistant powers of both leaders against the USA are significant. While Chávez influenced other Latin American movements to adopt his Chavismo model in an attempt at reforming South America, it was later deemed irritable and his influence was exaggerated internationally. Relations between Venezuela and the United States in particular deteriorated considerably as Chávez became strongly critical of U.S. foreign policy, criticized the 2003 U.S. invasion of Iraq and condemned the NATO-led military intervention in Libya. Relations with Obama were briefly thawed in June 2009, but only to eventually further deteriorate shortly 
afterwards. Chavez also concentrated on a number of multinational organizations, including Petro Caribe, Pterosaur and Tele SUR, in pursuing his vision for Latin American integrations. Bilateral commercial relations with other Latin American countries have played a major role in his agenda, by the arms acquisitions from Brazil, establishing trade agreements for oil-for-expertise with Cuba, and setting up specific trading arrangements to exchange Venezuelan oil for cash-strapped meat and dairy products from Argentina. He also became friends with pariah countries like Belarus and Iran. The country's domestic mishandling of Chávez stopped Venezuela from improving its position in the world. The former leaders have very distinct political genealogies. Chavez had a well-established political profile, which could be described as "leftist" in the sense that the word implies wide spectrum of social, political and economic perspectives.

Discourse Analysis of Ahmadinejad's speeches somewhat deployed the hegemony critically. As he announced that currently, an anti-hegemonic and anti-imperialist front was emerging, and all free nations and citizens seeking justice were join their hands together to build an extended front against the prevailing structure and thinking. That is CDA describes how political connections are practiced and negotiated within and around discourse that explains the third concept, is that discourse constitutes culture and society. Furthermore, concerning the relation between Iran and Venezuela, Ahmadinejad said that the Iranian-Venezuelan cooperation can be a model for anti-imperialist initiatives. This evaluated the constructiveness against the power of no means as of USA. The unprecedented ascension of Venezuelan President Hugo Chávez has generated a new interest in Latin America's ongoing populism. Like the charismatically populist Chávez, who preceded him, he soon became a symbol of deeper social division. In supporting a sharp incremental shift in Latin American politics, he was seen as a key individual and criticized for his authoritarian tendencies. Since then, Ahmadinejad's attempted to return to the popular policies of the early Islamic revolution and its political style of confrontation, his authoritarianism and his provocative remarks to the United States and Israel had made him a symbol of polarization and division.

Moreover, the detailed analysis presented in the preceding chapter not only provides answers to the general questions posed under the heading "Political Discourse," which is covered 
by Forough Rahimi's model of CDA (2011) based on van Dijk's framework and also applied by Zeb(2015), which has been used as research method and approach, but it also adequately answers the specified research questions about hegemonic, dominance, imperialism and counter discourse. This research also compared the speeches of both the leaders, highlighting the reasons for their resistance to US hegemonic dominance and comparing the similarities and differences in their speeches.

\section{Conclusion}

A summary of the research principles, challenges, observations and comparative analyses of Hugo Chavez and Ahmadinejad from Venezuela and Iran based on CDA clarifies some concepts in this context, such as language, text and semiology. This study analyzed the metaphors used by Venezuelan President Hugo Chavez to build and legitimize the revolutionary project known as the Bolivarian Revolution. On the other hand, Mahmoud Ahmadinejad deliberately assists him in explaining the various definitions and values embedded in Iranian identity. Ahmadinejad also pointed out that cooperation between Iran and Venezuela could serve as a model for antiimperialist initiatives with regard to Iran-Venezuela ties. This tests the strength of nothing like the United States constructively. He also talked on the debate on the political and social phenomena. In the end, the two leaders demonstrated their resistance successfully in their speeches in line with both international and local policies.

Furthermore, the speeches of the both leaders have been compared based on discourse. As the discourse can be viewed as an autonomous system of thinking or understanding which is based on the notion of "discourse" and which, according to this theory, often uses existing speeches as a mean of communication in society Hugo Chavez and Ahmadinejad made extensive use of resistance rhetoric at different events and at various audiences. He spoke negatively against the United States of America, despite belonging to a governed country, in an effort to question and fight hegemonic influence by using the most powerful weapon in one's hand language.

\section{References}

Abalo, E. (2015). Through a post-political gaze: on the ideological loading of democracy 
in the coverage of Chávez's Venezuela (Doctoral dissertation, Örebro university).

Aladist, I., \& Wahyudi, R. (2012). Treating disclaimer as a power strategy of self-legitimation And other-legitimation in Netanyahu's UNGA speech. Language \& Society, 2(1), 89-106.

Alemi, M., Tajeddin, Z., \& Rajabi Kondlaji, A. (2018). A discourse-historical analysis of two Iranian presidents' speeches at the UN General Assembly. International Journal of Society, Culture \& Language, 6(1), 1-17.

Blommaert, J., \& Bulcaen, C. (2000). Critical discourse analysis. Annual review of Anthropology, 29(1), 447-466.

Borszik, O. (2014). International sanctions against Iran under president Ahmadinejad: explaining regime persistence (No. 260). GIGA Working Papers.

Brown, K. (2005). Elsevier Encyclopedia of Language and Linguistics. Campbell, R. (2020). Framing US-Venezuelan Relations Under Bush and Chávez: Origins of A Country In Crisis.

Chaudhri, V., \& Fyke, J. P. (2008). Rhetoric in hostile diplomatic situations: A case study of Iranian President Mahmoud Ahmadinejad's rhetoric during his 2007 US visit. Place Branding and Public Diplomacy, 4(4), 317-330.

Darweesh, A. D., \& Muzhir, H. (2016). Representation of the Syrian crisis in the American political speeches: A critical discourse Analysis. International Journal of Language and Linguistics, 3(1), 40-48.

Fairclough, N., \& Wodak, R. (2008). The Bologna process and the knowledge-based economy: A critical discourse analysis approach. In Education and the knowledge-based economy in Europe (pp. 109-125). Brill Sense.

Farrelly, M. (2010). Critical discourse analysis in political studies: An illustrative analysis of the 'empowerment'agenda. Politics, 30(2), 98-104.

Foucault, M., \& Nazzaro, A. M. (1972). History, discourse and discontinuity. Salmagundi, (20), 225-248.

Fozi, N. (2016). Neo-iranian nationalism: Pre-islamic grandeur and shi'i eschatology in president mahmud ahmadinejad's rhetoric. The Middle East Journal, 70(2), 227-248. 
Gowhary, H., Rahimi, F. Azizifara, A., \& Jamalinesari, A. (2015). A critical discourse analysis Of the electoral talks of Iranian presidential candidates in 2013. Procedia - Social and Behavioral Sciences, 192, $132-141$

Gualda, R. J. R. (2012). The discourse of Hugo Chávez in "Aló Presidente": establishing the Bolivarian Revolution through television performance (Doctoral dissertation).

Hammond, J. R. (2014). Full Text of President Ahmadinejad's Remarks at UN Conference on Racism. Foreign Policy Journal Accessed, 8.

Kress, G. (1990). Critical discourse analysis. Annual review of applied linguistics, 11, 84-99 Mazlum, F., \& Afshin, S. (2016). Evaluative Language in Political Speeches: A Case Study of Iranian and American Presidents' Speeches. International Journal of Linguistics, 8 (4), 166-183.

McGregor, S. L. (2003). Critical discourse analysis: A primer. In Kappa Omicron Nu FORUM (Vol. 15, No. 1, pp. 15-1).

Pereira Stallaert, C. (2018). The strategic alliance between Chávez and Ahmadinejad, and its impact on international institutions, from a peripheral-realist perspective. Portuguese Journal of Social Science, 17(2), 179-197.

Rahimi, F., \& Riasati, M. J. (2011). Critical discourse analysis: Scrutinizing ideologically driven discourses. International journal of humanities and social science, 1(16), 107-112.

Rashidi, N., \& Souzandehfar, M. (2010). A critical discourse analysis of the debates between republicans and democrats over the continuation of war in Iraq. The Journal of Linguistic and Intercultural Education, 3, 55.

Rogers, R., Malancharuvil-Berkes, E., Mosley, M., Hui, D., \& Joseph, G. O. G. (2005). Critical discourse analysis in education: A review of the literature. Review of educational research, 75(3), 365-416.

Sabry, M. A Critical Discourse Analysis of the Conceptual Metaphor in Egyptians' Internet Language of Marriage.

SADEGHI, B., \& TABATABAI, S. M. (2015). Metaphor Analysis and Discursive Cycle of 
Iran's Foreign Policy:"Justice” through the lenses of US-IRAN Presidents. Cumhuriyet Üniversitesi Fen Edebiyat Fakültesi Fen Bilimleri Dergisi, 36(3), 2338-2358.

Sardabi, N., Biria, R., \& Azin, N. (2014). Rouhani's UN Speech: A Change in Ideology Or

Strategy. International Journal of Language Learning and Applied Linguistics World, 7(3), 84-97.

Shakoury, K. (2018). Critical Discourse Analysis of Iranian Presidents' Addresses to the United Nations General Assembly (2007-2016) (Doctoral dissertation, University of Saskatchewan)

Tayebipour, M. (2017, October). Unmasking the Ideological Stance of Political Leaders by Critical Discourse Analysis: Ahmadinejad as a Case Study. In International Symposium on Chaos, Complexity and Leadership (pp. 431-447). Springer, Cham.

Thaler, D. E., Nader, A., Chubin, S., Lynch, C., \& Green, J. D. (2010). Mullahs, Guards, and Bonyads: an exploration of Iranian leadership dynamics (Vol. 878): Rand Corporation.

Van Dijk, T. A. (1995). Discourse semantics and ideology. Discourse \& society, 6(2), 243-289.

Van Dijk, J. A. (1997). The reality of virtual community. Trends in communication, 1(1), 39-63. van Dijk, T. (2004). Discurso y dominación. Grandes conferencias en la Facultad de Ciencias Humanas, 4, 5-28.

Van Dijk, T. A. (2005). Discourse analysis as ideology analysis Language \& peace (pp. 41-58): Routledge.

Van Dijk, T.A. (2005). Politics, ideology and discourse. In R. Wodak (Ed.), Elsevier encyclopedia of language and linguistics. Volume on politics and language (pp. 728-740). Retrieved from http://www.discourse-in-society.org/teun.html.

Van Dijk, T. A. (2015). Critical discourse analysis. The handbook of discourse analysis, 466 485.

Van Dijk, T. A. (2010). Spoleczne aspekty nowych mediów, Analiza spoléczentwa sieci (Sociale aspecten van de nieuwe media, een sociaal-wetenschappelijke analyse). Widawnictwo PWN. 
Wilpert, G. (2007). Changing Venezuela by taking power: The history and policies of the Chávez government. Verso Books.

Wodak, R. (2011). Critical linguistics and critical discourse analysis. Discursive pragmatics, 50 69.

Zeb, S. (2015). Critical Discourse Analysis of Hugo Chavez' rhetoric: a study of dominance and resistance

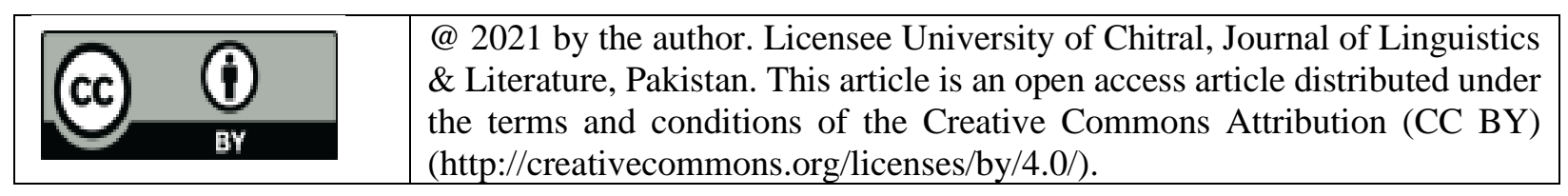

